\title{
Peptide release promoted by methylated RF2 and ArfA in nonstop translation is achieved by an induced-fit mechanism
}

\author{
FUXING ZENG and HONG JIN \\ Department of Biochemistry, Center for Biophysics and Quantitative Biology, University of Illinois at Urbana-Champaign, Urbana, \\ Illinois 61801, USA
}

\begin{abstract}
Here we report that the specificity of peptide release in the ribosome on a nonstop mRNA by ArfA and RF2 is achieved by an induced-fit mechanism. Using RF2 that is methylated on the glutamine of its GGQ motif (RF2 ${ }^{\mathrm{m}}$ ), we show that methylation substantially increases the rate of ArfA/RF2-catalyzed peptide release on a nonstop mRNA that does not occupy the ribosomal A site, but has only a modest effect on $k_{\text {cat }}$ by the same proteins on longer nonstop mRNAs occupying the A site of the mRNA channel in the ribosome. Our data suggest that enhancement in the $k_{\text {cat }}$ of peptide release by ArfA and RF2 under the cognate decoding condition is the result of favorable conformational changes in the nonstop complex. We demonstrate a shared mechanism between canonical and nonstop termination, supported by similarities in the kinetic mechanisms in antibiotic inhibition and methylation-correlated enhancement in the rate of peptide release. Despite these similarities, our data suggest that nonstop termination differs from canonical pathway in the downstream event of recycling.
\end{abstract}

Keywords: ribosome; quality control; translational termination; nonstop translation; RF2; alternative rescuing factor A

\section{INTRODUCTION}

The coupling of transcription and translation in the same cellular compartment enables bacterial cells to replicate rapidly and to respond swiftly to environmental changes. The time required to express protein products of a gene is minimized by having mRNA translation begin before transcription is complete. However, this coupling of transcription and translation poses challenges for protein quality control because bacterial cells cannot monitor the integrity of an mRNA before starting to translate it. Therefore, a ribosome can end up translating a truncated mRNA that has no stop codon. The end result will be a ribosome stalled on an mRNA that cannot elongate or terminate the nascent peptide chain, because its aminoacyl (A) site is unoccupied. This is called nonstop translation.

It is estimated that $\sim 2 \%-4 \%$ of translations are nonstop translations in Escherichia coli (Ito et al. 2011). This implies that the average ribosome is involved in about five nonstop translation events per cell division cycle (Keiler and Feaga 2014). Thus, stalled ribosomes must be quickly identified and rescued to ensure that both the quantity and the quality of protein synthesis in a cell are not compromised. Bacteria have evolved three mechanisms for releasing stalled ribosomes and resolving nonstop translation events: (1) a trans-

Corresponding author: hjin@illinois.edu

Article published online ahead of print. Article and publication date are at http://www.rnajournal.org/cgi/doi/10.1261/rna.053082.115. translation system involving transfer-messenger RNA and small protein $\mathrm{B}$ (tmRNA-SmpB) that rescues ribosomes and targets nonstop mRNAs and nascent polypeptides for rapid degradation; (2) alternative ribosome rescuing factor $A$ and release factor 2 (ArfA/RF2); and (3) alternative ribosome rescuing factor $\mathrm{B}(\mathrm{ArfB})$ which releases the nascent peptide and enables stalled ribosomes to recycle. Genetic studies have suggested that nearly all the bacteria species require at least one of the above mechanisms for ribosome rescue in order to survive (Chadani et al. 2010).

$\mathrm{RF} 2$, one of the class I protein release factors that participate in normal translational termination, plays a unique role in controlling the quality of the protein synthesis in bacteria. In normal termination, class I release factors in bacteria, $\mathrm{RF} 1$, and $\mathrm{RF} 2$, bind to the translating ribosome when one of the three near-universal stop codons on an mRNA is encountered in the A site of the small ribosomal subunit. Stop codons are decoded in the ribosome in a manner that is fundamentally different from sense codons. Decoding is done by proteins instead of tRNAs. RF1 and RF2 recognize the three stop codons with overlapping specificity: RF1 recognizes UAG, RF2 recognizes UGA, and both of them

(C) 2015 Zeng and Jin This article is distributed exclusively by the RNA Society for the first 12 months after the full-issue publication date (see http://rnajournal.cshlp.org/site/misc/terms.xhtml). After 12 months, it is available under a Creative Commons License (Attribution-NonCommercial 4.0 International), as described at http://creativecommons.org/licenses/by$\mathrm{nc} / 4.0 /$. 
recognize UAA (Scolnick et al. 1968). Upon stop codon recognition, class I release factors promote the hydrolysis of peptidyl tRNA in the ribosomal peptidyl (P) site, terminating protein synthesis (Capecchi 1967; Caskey et al. 1968; Scolnick et al. 1968).

The elements of release factors involved in the stop codon recognition and catalysis of peptide release have been revealed using genetics, biochemistry, and sequence analysis. An elegant genetic experiment demonstrated that exchanging a tripeptide motif between RF1 and RF2 (P[A/V]T in RF1; SPF in RF2) switches their respective specificities for UAG and UGA (Ito et al. 2000). A universally conserved tripeptide sequence, GGQ, has been implicated in the hydrolysis of the nascent peptide from P-tRNA (Frolova et al. 1999). Hydroxyl-radical probing has suggested that the SPF and GGQ motifs of RF2 are close to the decoding center and peptidyl transferase center (PTC), respectively, when bound to the ribosome (Wilson et al. 2000). These locations for the decoding (P[V/A]T, SPF) and catalytic (GGQ) motifs of the release factors on a ribosome were confirmed by both cryoEM (Klaholz et al. 2003; Rawat et al. 2003) and low-resolution crystallographic structures (Petry et al. 2005).

Crystal structures of the $70 \mathrm{~S}$ ribosome complexed with class I release factors and their cognate stop codons, which have been solved at a near-atomic resolution (Korostelev et al. 2008; Laurberg et al. 2008; Weixlbaumer et al. 2008; Jin et al. 2010), have provided us a clear picture of the translational termination in three dimensions. The interactions of RF2 with its cognate stop codons in the decoding center revealed by the crystal structures offers molecular explanations for the specificity of stop codon recognition in the ribosome (Korostelev et al. 2008; Weixlbaumer et al. 2008). For the peptide release, the catalytic GGQ motif in the release factors makes extensive interactions in the PTC (Laurberg et al. 2008; Weixlbaumer et al. 2008; Jin et al. 2010). This catalytic motif is positioned in the PTC by a network of hydrogen bond interactions between highly conserved residues in release factors and nucleotides in the 23S rRNA (Jin et al. 2010). The conformation of the glycines in the GGQ motif facilitates proper placement of the conserved glutamine in the core of the PTC, where it forms a densely packed pocket with the A76 of the peptidyl tRNA, and A2451, C2063, U2585, and U2506 of the 23S rRNA for the catalysis of the peptide release.

Biochemical and structural studies on tmRNA/SmpB-mediated (Ivanova et al. 2004; Neubauer et al. 2012) and ArfBmediated (Gagnon et al. 2012) pathways involved in rescuing a stalled ribosome in the nonstop translation have provided insight into functions of these ribosome-bound factors in releasing the nascent peptide in the ribosome. Chadani et al. (2010) discovered that ArfA is essential for the viability of $E$. coli in the absence of tmRNA-mediated trans-translation system using a synthetic lethal screen. The expression of ArfA in E. coli and ArfA-homolog proteins in other bacteria species is regulated by RNase III and tmRNA (Chadani et al. 2011;
Garza-Sanchez et al. 2011; Schaub et al. 2012). Class I release factor RF2 is essential for ArfA's function in the cell (Chadani et al. 2012; Shimizu 2012). Remarkably, only the GGQ motif in RF2 is important for the peptide release catalyzed by ArfA and RF2; its SPF motif is dispensable (Chadani et al. 2012).

Despite these exciting advances in our understanding of the translational termination and quality control of protein synthesis, several important questions remain to be answered. The GGQ motif that is required for catalytic activity (Song et al. 2000; Mora et al. 2003) of peptide release is universally conserved. Importantly, the glutamine in this motif is invariably methylated post-translationally at the $N^{5}$ position. This methylation had been reported to have a noticeable effect on the RF2-dependent but not RF1-dependent release activity in E. coli in vitro (Dincbas-Renquist et al. 2000). The same modification is also found in Saccharomyces cerevisiae and is required for optimal cell growth (HeurguéHamard et al. 2005). The packing role of the side chain of the glutamine for the catalysis of peptide release has been demonstrated biochemically (Shaw and Green 2007), structurally (Jin et al. 2010), and computationally (Trobro and Aqvist 2007, 2009). The enhanced packing of the $N^{5}$-methylation of the catalytic glutamine in the GGQ motif has been suggested by computational studies (Trobro and Aqvist 2007). It is conceivable that the precise conformation of the glutamine in the ribosome will be influenced by this methylation that normally occurs in vivo. However, the effect of the methylation on the catalysis of the peptide release has not been investigated in most recent kinetic studies, nor has its effects on the termination events involved in the quality control processes been evaluated.

Second, how RF2 catalyzes peptide release on a truncated mRNA in the ribosome remains elusive. In any case, decoding by RF2 appears to be more complicated than that of RF1 (Petropoulos et al. 2014). Furthermore, a so-called "negativeto-positive charge-flip" mutation E167K in RF2 was reported to trigger the peptide release not only at the three conserved stop codons, but also at the sense codons such as UGG, UAC, and UUA (Ito et al. 1998). A similar phenomenon has not been observed in RF1. While much has been learned about the tmRNA-SmpB and ArfB pathways for resolving nonstop translation from the structures of ribosomal complexes with those proteins bound (Gagnon et al. 2012; Neubauer et al. 2012), the molecular interactions that enable the ribosome to sense a nonstop mRNA and recruit ArfA and RF2 for the peptide release are unknown.

Here, we obtained fully methylated RF2 (RF2 $\left.{ }^{\mathrm{m}}\right)$ by coexpressing wild-type RF2 and its cognate methyltransferase PrmC under mild lactose induction in E. coli. Using the $\mathrm{RF} 2{ }^{\mathrm{m}}$ obtained by this method, we have measured the kinetics of peptide release on nonstop mRNAs by ArfA/RF2 ${ }^{\mathrm{m}}$ in $E$. coli. Our results suggest that ArfA/RF2 catalyze peptide release by the induced-fit mechanism that broadly resembles tRNA-selection in the ribosome. More specifically, ArfA helps induce a fully activated conformation of RF2 to release 
nascent peptides in the PTC when the ribosome encounters the end of a nonstop mRNA.

\section{RESULTS}

To ensure that we accurately elucidated molecular determinants in RF2 that contributed to catalysis of the peptide release in nonstop termination pathways, we used RF2 with fully methylated glutamine in its GGQ sequence for in vitro kinetic assays. Chromosomally expressed RF2 was used for this purpose (Dincbas-Renqvist et al. 2000), but the yield obtained when RF2 is prepared this way is low. More recently, methylated RF2 was obtained by in vitro enzymatic reaction (Kuhlenkoetter et al. 2011). Coexpression of the prm C methylase gene and RF2 was suggested to obtain methylated RF2 (Fei et al. 2010), but results on the methylation status by this method were not reported.

Here we cloned the prmC gene from E. coli as PCR-generated NdeI-XhoI fragments into pET-22b vector with an ampicillin resistance marker, and we also cloned release factor RF2 from E. coli K12 strain into pET-13 with a kanamycin resistance marker (Weixlbaumer et al. 2008; Jin et al. 2010). Next, fully methylated RF2 was obtained by cotransformation of the PrmC and RF2 clones into the E. coli BL21 (DE3) strain and expression with a very mild induction using lactose at $25^{\circ} \mathrm{C}$ (Supplemental Fig. S1A; Monteiro et al. 2000). RF2 was then purified by affinity, ion-exchange, and size-exclusion chromatography, and the methylation status of RF2 was examined by mass spectrometry (Supplemental Fig. S1B,C). Using this method, we obtained $100 \%$ methylated RF2.

\section{ArfA binds to RF2, not RF1, near the decoding center of the ribosome}

The catalytic mechanism of ArfA/RF2-mediated termination that bacteria use to resolve stalled ribosomes in nonstop translation is unknown. In the absence of a three-dimensional structure, even the location of the binding site of ArfA on the ribosome remains controversial. It has been suggested that ArfA binds to the 70S, 50S, or, more recently, to the 30S (Chadani et al. 2011; Kurita et al. 2014).

The expression of the wild-type ArfA in the cell is subject to the regulation of RNase III and tmRNA-SmpB activity (Chadani et al. 2011; Garza-Sanchez et al. 2011; Schaub et al. 2012). In the absence of the tmRNA-SmpB system, the C-terminal 17 amino acids truncated protein ArfA $\triangle 17 \mathrm{C}$ is produced, and it has been suggested that this is the form of the protein that recruits RF2 to rescue the stalled ribosome (Garza-Sanchez et al. 2011; Schaub et al. 2012). Different truncated ArfA proteins that lack C-terminal $12,17,22,25$, and 32 amino acids were constructed, and these variants all showed a similar ribosome-rescuing activity, except for ArfA $\Delta 32 \mathrm{C}$ (Chadani et al. 2011). Thus, E. coli ArfA $\triangle 12 \mathrm{C}$ was cloned, expressed, and purified for the rest of this study.
The association of ribosomal subunits with ArfA $\Delta 12 \mathrm{C}$ was tested in the following experiment. Complexes comprised of $70 \mathrm{~S}$ ribosome, RF2, ArfA $\triangle 12 \mathrm{C}$, and nonstop mRNAs were first assembled in vitro. The complexes were then passed through two rounds of linear sucrose gradients with different $\mathrm{Mg}^{2+}$ concentrations. The homogenous ribosomal complex of 70S/RF2/ArfA $\Delta 12 \mathrm{C}$ was obtained from the first sucrose gradient with $10 \mathrm{mM} \mathrm{Mg}^{2+}$ concentration. The subunits of $70 \mathrm{~S}$ ribosome were split using the second sucrose gradient with $2 \mathrm{mM} \mathrm{Mg}^{2+}$. Results from Western blot showed that ArfA $\triangle 12 \mathrm{C}$ bound to the $70 \mathrm{~S}$ ribosome (Fig. 1A, Lane 2) and had a stronger affinity for the $30 \mathrm{~S}$ than for the $50 \mathrm{~S}$ subunit (Fig. 1A, Lane 4). It was proposed previously that ArfA binds to the 50S subunit of the ribosome (Chadani et al. 2010; Kurita et al. 2014). However, the experiments in question were done using a cell-based assay with the cellular mRNA pool and overexpressed ArfA protein or by incubating ArfA with purified ribosomal subunits, instead of by
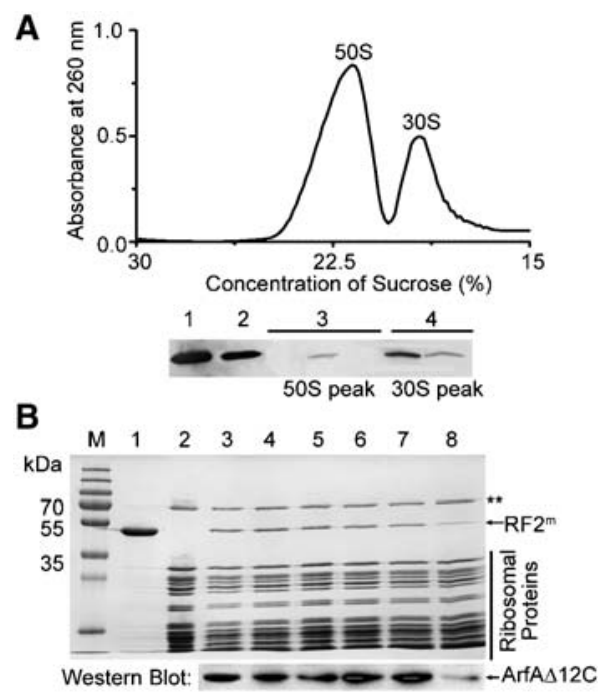

\begin{tabular}{cccccc}
\hline Lane & $70 \mathrm{~S}$ & mRNA & P-tRNA & ArfA $\triangle 12 \mathrm{C}$ & RF2 $^{\mathrm{m}}$ \\
\hline 1 & - & - & - & - & + \\
2 & + & - & - & - & - \\
3 & + & $\mathrm{A} 0$ & + & + & + \\
4 & + & $\mathrm{A} 3$ & + & + & + \\
5 & + & $\mathrm{A} 6$ & + & + & + \\
6 & + & $\mathrm{A} 9$ & + & + & + \\
7 & + & $\mathrm{A} 12$ & + & + & + \\
8 & + & $\mathrm{A} 0$ & + & A18T & + \\
\hline
\end{tabular}

FIGURE 1. Interaction of ArfA to the ribosome. (A) ArfA $\triangle 12 \mathrm{C}$ binds to the $70 \mathrm{~S}$ ribosome and has a stronger affinity to the $30 \mathrm{~S}$ subunit. Using antibodies against the His-tag fused to ArfA $\Delta 12 \mathrm{C}$, results from Western blots on His-tagged ArfA $\triangle 12 \mathrm{C}$ alone (Lane 1), on $70 \mathrm{~S}$ pool (Lane 2), on separated subunits 50S (Lane 3), and 30S (Lane 4) pools. (B) Association of ArfA $\Delta 12 \mathrm{C}$ and RF2 ${ }^{\mathrm{m}}$ with the ribosome on a nonstop mRNA. SDS-gel showing components of the nonstop ribosomal complexes after gel filtration. ArfA $\triangle 12 \mathrm{C}$ and $\mathrm{RF} 2^{\mathrm{m}}$ bind to the ribosome on different nonstop mRNAs (top gel). Western blot of His-tagged ArfA $\triangle 12 \mathrm{C}$ shows that ArfA $\Delta 12 \mathrm{C}$ has a similar binding affinity to different ribosomal nonstop complexes (bottom gel). Mutant ArfA $\Delta 12 \mathrm{C}$ (A18T) inhibits binding of the protein to the ribosome (Lane 8$).\left({ }^{* *}\right)$ Ribosomal protein S1. 
reconstituting a nonstop system using a truncated mRNA and stoichiometric amount of ArfA/RF2 as we did. These differences may account for the difference between their results and ours. Moreover, our results are consistent with the chemical probing data that were published most recently (Kurita et al. 2014).

Next, the association of ArfA $\Delta 12 \mathrm{C}$ with the ribosome carrying a nonstop mRNA in the presence of RF2 and RF1 was tested. As expected, RF2, not RF1, bound to the ribosome in the presence of ArfA (Fig. 1B; Supplemental Fig. S2). In the absence of ArfA, RF2 did not bind to the ribosome when the ribosomal A-site was empty or occupied with a sense codon (Supplemental Fig. S2). Furthermore, our results show that ArfA $\triangle 12 \mathrm{C}$ and RF2 associate with the ribosome carrying a nonstop mRNA not only when the ribosomal A-site is empty (Fig. 1B, lane 3), but also, with a similar affinity, when the A-site is occupied with a sense codon (Fig. 1B, lanes 4-7).

\section{In the presence of ArfA, RF2 specifically catalyzes peptide release in the ribosome on a nonstop mRNA}

To measure the kinetics of peptide release by ArfA and RF2, we used a peptide release assay similar to the one described by Green and colleagues (Zaher and Green 2009; Petropoulos et al. 2014) with modifications (see Materials and Methods). This assay follows the rate of release of $f-\left[{ }^{35} \mathrm{~S}\right]-$ Met from initiator tRNA f- $\left[{ }^{35} \mathrm{~S}\right]-$ Met-tRNA ${ }^{\text {fMet }}$ bound in the $\mathrm{P}$ site of the ribosome by RF2. Nonstop translational complexes comprised of ribosome, nonstop mRNA, P-site $\mathrm{f}-\left[{ }^{35} \mathrm{~S}\right]-$ Met-tRNA $^{\mathrm{fMet}}$, and ArfA $\Delta 12 \mathrm{C}$ were formed using methods similar to one that has been used for the formation of canonical termination complexes (Zaher and Green 2009; Petropoulos et al. 2014). Different concentrations of ArfA $\triangle 12 \mathrm{C}$ were tested to ensure that a stable association of ArfA $\triangle 12 \mathrm{C}$ to the ribosome was achieved (Fig. 2A). In the buffer conditions that we used, a 2.5-fold excess of ArfA $\triangle 12 \mathrm{C}$ was chosen for reconstituting the nonstop ribosomal complex for kinetic studies.
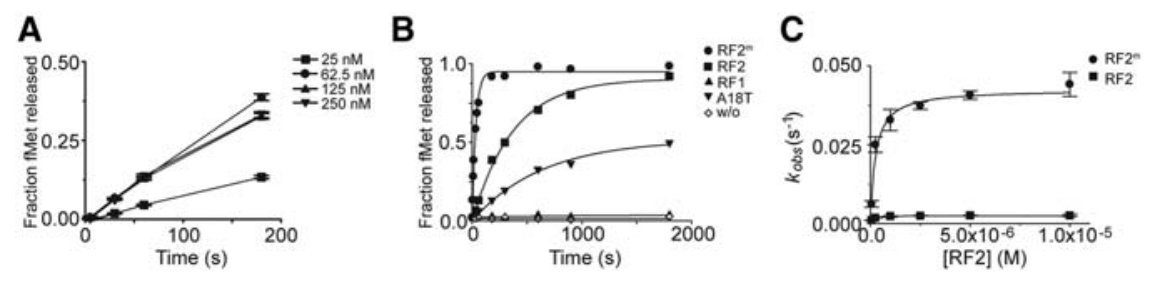

FIGURE 2. ArfA $\triangle 12 \mathrm{C}$ and $\mathrm{RF} 2^{\mathrm{m}}$ promote peptide release on a nonstop mRNA in the ribosome. (A) ArfA $\triangle 12 \mathrm{C}$ titrations for establishing reproducible kinetic behavior including formation of a stable nonstop complex and achieving a high reaction end point. (B) Representative time courses of peptide release at $25 \mathrm{nM}$ nonstop ribosomal complexes by fully methylated $\mathrm{RF} 2^{\mathrm{m}}(\bullet)$, unmeth-

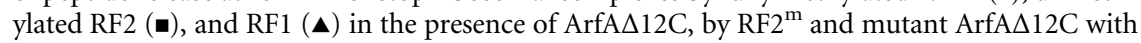
A18T point mutation $(\mathbf{v})$ and by RF2 ${ }^{\mathrm{m}}(\diamond)$ in the absence of ArfA $\Delta 12 \mathrm{C}$. In every case, the concentrations of proteins are as follows: $62.5 \mathrm{nM}$ ArfA $\Delta 12 \mathrm{C}, 5 \mu \mathrm{M} \mathrm{RF} 2^{\mathrm{m}}, 5 \mu \mathrm{M} \mathrm{RF} 2$, and $5 \mu \mathrm{M} \mathrm{RF} 1$. (C) Observed rate versus RF2 concentrations showing fits for catalytic rate constant $k_{\text {cat }}$ and $K_{1 / 2}$ calculations.
Next, titrations of different concentrations of RF2 were carried out to establish conditions where the ribosomes were saturated with RF2 (data not shown). Rate constants for peptide release by RF2 on nonstop mRNAs were measured in triplicate at six different concentrations of RF2, and the average rate constants were plotted versus RF2 concentrations (Fig. 2B,C). The $k_{\text {cat }}$ and $K_{1 / 2}$ were obtained by fitting the data to the Michaelis-Menten equation and the results are summarized in Table 1 . All the data were obtained at $37^{\circ} \mathrm{C}$ in a buffer containing $10 \mathrm{mM} \mathrm{MgCl}_{2}$ and represent averages from at least three independent experiments using independently purified nonstop complexes. The $k_{\text {cat }}$ and $K_{1 / 2}$ of fMet-release by $\mathrm{RF} 2^{\mathrm{m}}$ on stop codon UGA obtained in this study were in good agreement with previously published data using chromosomally expressed RF2 from E. coli K12 strain (Dincbas-Renqvist et al. 2000).

Consistent with the data shown in Supplemental Figure S2, $\mathrm{RF} 2^{\mathrm{m}}$ did not release $\mathrm{fMet}$ on a nonstop mRNA in the ribosome when the ArfA was absent (Fig. 2B). Not surprisingly, only RF2, not RF1, catalyzed the peptide release in the presense of ArfA. Remarkably, the $k_{\text {cat }}$ by $\mathrm{RF} 2^{\mathrm{m}}$ was $\sim 20$-fold higher than the one obtained using unmethylated protein, although $K_{1 / 2}$ remained almost unchanged (Table 1; Fig. 2C). This result suggests that $N^{5}$-methylation of the glutamine in the GGQ motif significantly stimulates peptide release in ArfA/RF2-mediated termination. We observed a similar change of $k_{\text {cat }}$ and $K_{1 / 2}$ results by glutamine $N^{5}$-methylation in RF2 on a cognate stop codon (an $\sim 10$-fold increase in $k_{\text {cat }}$, Table 1). These observations suggest that ArfA emulates a cognate stop codon UGA in the decoding center when it interacts with RF2, and this interaction leads to a fully induced state of RF2 for the subsequent peptide release over $75 \AA$ away in the PTC.

An A18T mutation in the ArfA has been reported to affect the peptide release but leave the ribosome association of RF2 unchanged (Shimizu 2012). To study the effect of this mutation on the kinetic profile of peptide release, we made a mutant protein ArfA $\Delta 12 \mathrm{C}(\mathrm{A} 18 \mathrm{~T})$ by site-directed mutagenesis and examined its behavior. The A18T mutant could bind to the RF2 in the ribosome, although the interaction appeared to be somewhat compromised, as suggested by a fainter band in the binding experiment (Fig. 1B, lane 8 ). Methylation at the glutamine in the GGQ sequence makes a difference in the peptide release by RF2 that has been recruited to the ribosome by the mutant. With an unmethylated RF2, the rate constant of the fMet release was too low to be measured accurately. However, with the $N^{5}$-methylated $\mathrm{RF} 2^{\mathrm{m}}$, the catalytic rate constant dropped more than 11-fold, and binding was compromised by about sixfold as a result of the point mutation in the ArfA (Table 1). Furthermore, the 
TABLE 1. Rate and binding constants of peptide release for different ribosomal complexes

\begin{tabular}{|c|c|c|c|c|c|}
\hline \multirow[b]{2}{*}{ Ribosomal complex } & \multirow[b]{2}{*}{ mRNA } & \multicolumn{2}{|c|}{$\mathrm{RF} 2^{\mathrm{m}}$} & \multicolumn{2}{|c|}{ RF2 } \\
\hline & & $k_{\text {cat }}\left(\mathrm{s}^{-1}\right)$ & $K_{1 / 2}\left(10^{-6} \mathrm{M}\right)$ & $k_{\text {cat }}\left(\mathrm{s}^{-1}\right)$ & $K_{1 / 2}\left(10^{-6} \mathrm{M}\right)$ \\
\hline \multirow[t]{5}{*}{$\operatorname{ArfA} \Delta 12 \mathrm{C}$} & SD-PMet-0 & $0.0419 \pm 0.0007$ & $0.19 \pm 0.03$ & $0.0025 \pm 0.0001$ & $0.12 \pm 0.02$ \\
\hline & SD-PMet-3 & $0.0203 \pm 0.0005$ & $0.22 \pm 0.03$ & $0.0022 \pm 0.0002$ & $0.31 \pm 0.10$ \\
\hline & SD-PMet-6 & $0.00092 \pm 0.00004$ & $1.13 \pm 0.16$ & $0.00038 \pm 0.00001$ & $1.71 \pm 0.13$ \\
\hline & SD-PMet-9 & ND & ND & ND & ND \\
\hline & SD-PMet-12 & - & - & ND & ND \\
\hline $\operatorname{ArfA} \Delta 12 \mathrm{C}-\mathrm{A} 18 \mathrm{~T}$ & SD-PMet-0 & $0.0038 \pm 0.0002$ & $1.14 \pm 0.28$ & ND & ND \\
\hline Cognate stop codon & SD-PMet-UGA & $0.083 \pm 0.001$ & $0.07 \pm 0.01$ & $0.0091 \pm 0.0002$ & $0.11 \pm 0.01$ \\
\hline Near-cognate stop codon & SD-PMet-UGG & $0.0039 \pm 0.0006$ & $4.10 \pm 1.46$ & $0.0010 \pm 0.0001$ & $4.58 \pm 0.76$ \\
\hline
\end{tabular}

Errors were calculated by standard error propagation. (ND) The rates were unmeasurably slow. (-) The rates were not measured.

end point of the release reaction was decreased by about half by the mutant when compared to the one by the wild-type ArfA $\triangle 12 C$ (Fig. 2B). These results indicate that the A18T mutation in the ArfA might inhibit the formation of a fully induced conformation of RF2. The observed effect was most likely due to an interruption of important hydrophobic interactions between the two proteins as a result of the A18T point mutation.

\section{Occupancy level of mRNA channel in the ribosome influences ArfA/RF2-mediated peptide release in nonstop translation}

Sensing the empty mRNA channel in the A-site by external proteins that bind to the ribosome was suggested to be essential to resolving nonstop translation (Gagnon et al. 2012; Neubauer et al. 2012). However, it has been shown that the mRNA channel does not need to be empty for the ribosome rescue to occur (Ivanova et al. 2004; Shimizu 2012). Consistent with these results, we have found that ArfA $\triangle 12 \mathrm{C}$ and $\mathrm{RF} 2{ }^{\mathrm{m}}$ bind to the ribosome with similar affinity when the mRNA channel in the A-site of the 30 S subunit is occupied (Fig. 1B). Using single-turnover kinetic experiments, we studied the kinetics of the peptide release on nonstop mRNAs with varying lengths in the mRNA channel (Table 1; Fig. 3). Our results showed a drastic decrease in the $k_{\text {cat }}$ of the fMet release when the number of nucleotides occupying the mRNA channel downstream from the $\mathrm{P}$ site increased. mRNAs with 9 nucleotides (nt) following the $\mathrm{P}$ site showed almost no fMet release by ArfA $\Delta 12 \mathrm{C}$ and $\mathrm{RF} 2^{\mathrm{m}}$ in the ribosome under the experimental conditions that we used. The rate constant dropped by half when only one triplet codon was added (termed A3 mRNA) compared to the A0 mRNA; but it decreased by $\sim 45$-fold when two triplet codons were added (termed A6 mRNA). In contrast to the changes in $k_{\text {cat }}, K_{1 / 2}$ showed a mild change with about sixfold increase on A6 compared to A0 mRNA.

Furthermore, methylation in the GGQ motif of the RF2 only mildly influenced the rate constant of peptide release on A6 mRNA in the ribosome. As shown in Table 1, com- pared to about a 20 -fold increase on $\mathrm{A} 0, k_{\text {cat }}$ of the fMet release increases by 10 -fold on A3 and only 2.4-fold on A6 mRNA when RF2 is methylated in the GGQ motif, similar
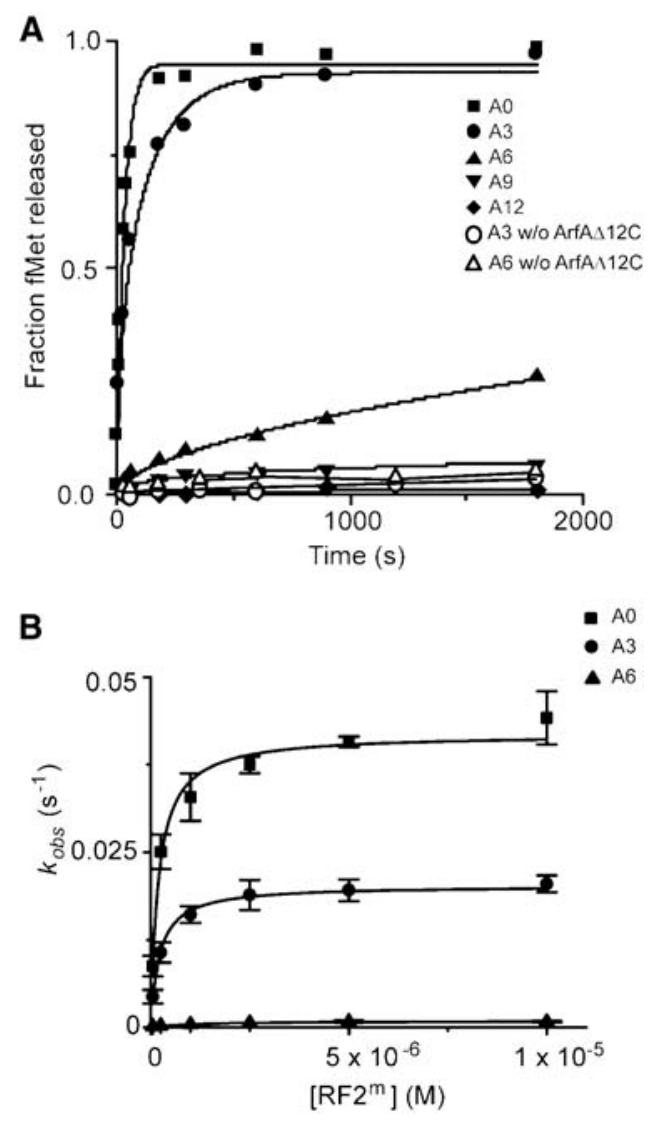

FIGURE 3. Peptide release by ArfA $\triangle 12 \mathrm{C}$ and $\mathrm{RF} 2^{\mathrm{m}}$ on different nonstop mRNAs in the ribosome. (A) Representative time courses of peptide release at $25 \mathrm{nM}$ ribosomes by $62.5 \mathrm{nM}$ ArfA $\Delta 12 \mathrm{C}$ and $5 \mu \mathrm{M}$ $\mathrm{RF}^{\mathrm{m}}{ }^{\mathrm{m}}$ on nonstop mRNAs A0 $(\boldsymbol{\bullet}), \mathrm{A} 3(\bullet), \mathrm{A} 6(\boldsymbol{\Delta}), \mathrm{A} 9(\boldsymbol{\nabla})$, and A12 $(\diamond)$. Time courses of peptide release at $25 \mathrm{nM}$ ribosomes by $5 \mu \mathrm{M}$ $\mathrm{RF}^{\mathrm{m}}$ on nonstop mRNAs A3 $(\mathrm{O})$ and $\mathrm{A} 6(\Delta)$ in the absence of ArfA $\triangle 12 \mathrm{C}$ were also shown. $(B)$ Observed rate versus RF2 ${ }^{\mathrm{m}}$ concentrations showing fits for catalytic rate constant $k_{\text {cat }}$ and $K_{1 / 2}$ calculations for

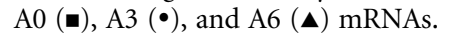


to what we have observed in the changes of rate constants by the methylation of RF2 on a near-cognate stop codon in canonical termination. Assuming the rate-limiting step of the pathway is not changed due to the length of mRNAs or the $N^{5}$-methylation in the glutamine, a straightforward explanation of this observation is that nucleotides downstream from the $\mathrm{P}$ site inhibit the formation of a fully activated conformation of ArfA and RF2, which results in a sub-optimal placement of the glutamine in the PTC for the peptide release.

Finally, end points of the fMet release reaction by ArfA/ $\mathrm{RF} 2^{\mathrm{m}}$ decreased when the number of nucleotides increased (Fig. 3A), and the end point deficiency for the peptide release could not be overcome by raising the concentrations of $\mathrm{Mg}^{2+}$ (Supplemental Fig. S3A) for A6 and A9 mRNAs. This is a strong indication that conformations of the nonstop complexes formed on longer nonstop mRNAs (A6 and A9 mRNAs) and that of the complex formed on A0 mRNA are different.

\section{Peptide release by $\mathrm{RF}^{\mathrm{m}}$ on a truncated mRNA in the ribosome is sensitive to viomycin and paramomycin}

To further probe the nature of ArfA/RF2-mediated decoding on a nonstop mRNA, we studied the kinetic behavior of the process in the presence of antibiotics paromomycin and viomycin. Both antibiotics bind in the decoding center and are known to inhibit the translocation step of protein synthesis. The effect of paromomycin on peptide release was studied in canonical termination. Paromomycin belongs to the aminoglycoside antibiotic family; it binds in the major groove of helix 44 (h44) in the decoding center of the ribosome and promotes A1492 and A1493 to "flip out" the h44 helix, thereby stabilizing a conformation of the decoding center in a state that would only adopt when the correct codon-anticodon interactions take place. While promoting the tRNA binding and miscoding events, paromomycin binds competitively to the ribosome with RF1 (Youngman et al. 2007), hence it inhibits the translation termination.

Viomycin is one of tuberactinomycin antibiotics; it binds at the junction formed by h44 of the 16S rRNA and helix 69 (H69) from the 23S rRNA (Stanley et al. 2010). Viomycin inhibits translocation by stabilizing A-tRNA binding to the ribosome, leaving functions of EF-G, including its association to the ribosome and GTP hydrolysis, largely unaltered (Modolell and Vázquez 1977; Yamada et al. 1978). In translational termination, H69 interacts with the RF2 and h44 in the $30 \mathrm{~S}$ subunit, establishing a connection between the decoding center and PTC. Therefore, it is possible that viomycin would inhibit peptide release, but experimental evidence is required to confirm this argument.

To study the effect of these antibiotics on peptide release catalyzed by ArfA/RF2 in a nonstop complex, we formed the nonstop complexes in the presence of the antibiotics and examined the rate of fMet release by $\mathrm{RF} 2 \mathrm{~m}$. Our results showed that under a high concentration $(500 \mu \mathrm{M})$, both an- tibiotics inhibited peptide release with viomycin, showing a more pronounced effect (Fig. 4A). We also obtained the same results for the $\mathrm{RF} 2^{\mathrm{m}}$-catalyzed peptide release on stop codon UGA (Fig. 4B).

We further investigated the inhibitory effects of various concentrations $(0-150 \mu \mathrm{M})$ of paromomycin on different nonstop complexes (Fig. 4C-J). Our results showed that when the concentration of paromomycin was below 150 $\mu \mathrm{M}$, the $k_{\text {cat }}$ of peptide release by ArfA $\Delta 12 \mathrm{C} / \mathrm{RF} 2^{\mathrm{m}}$ in the ribosome on A0 nonstop mRNA stayed nearly the same, but $K_{1 / 2}$ increased as the concentrations of paromomycin increased (Fig. 4C,D). Similar degrees of the change in kinetic profiles represented by $k_{\text {cat }}$ and $K_{1 / 2}$ were seen on stop codon
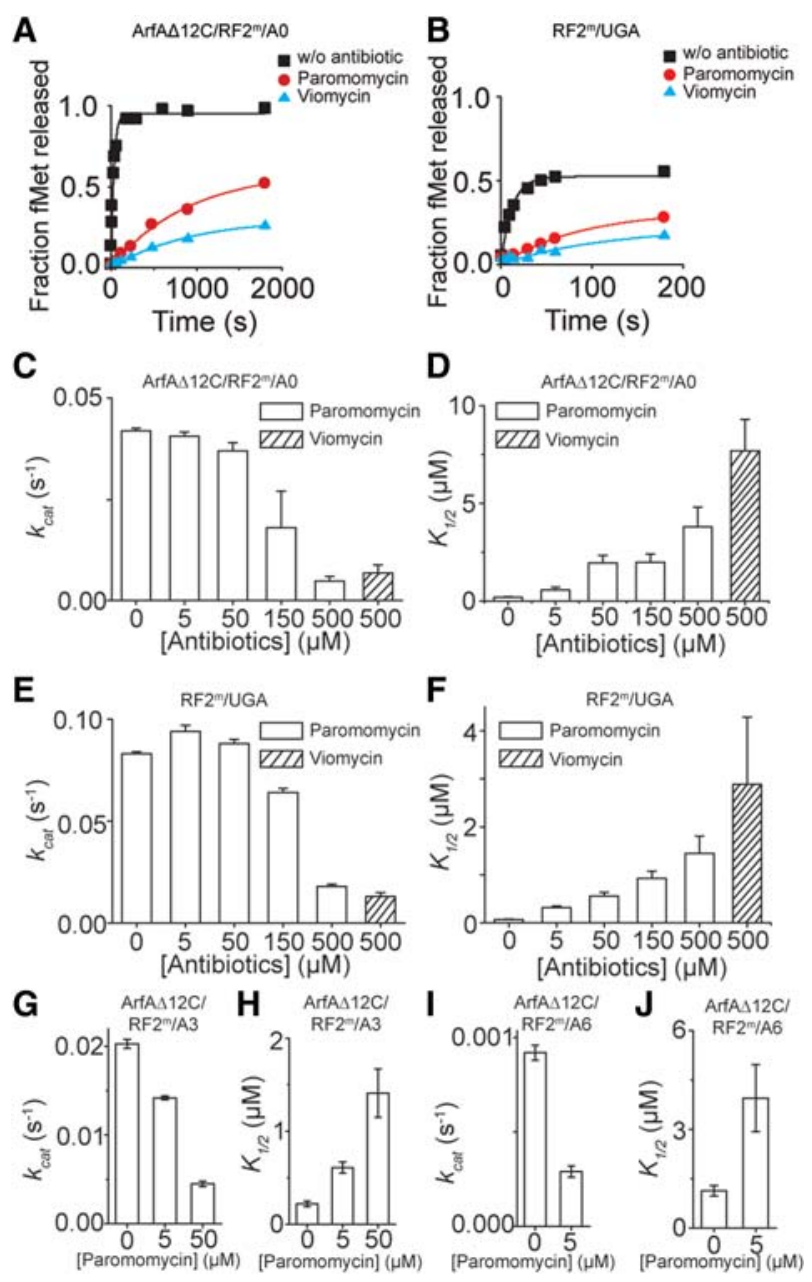

FIGURE 4. The effects of antibiotics viomycin and paromomycin on peptide release. Representative time courses of peptide release: $(A)$ on A0 nonstop mRNA at $25 \mathrm{nM}$ ribosomes by $62.5 \mathrm{nM}$ ArfA $\Delta 12 \mathrm{C}$ and 5 $\mu \mathrm{M} \mathrm{RF} 2^{\mathrm{m}} ;(B)$ on stop codon UGA at $25 \mathrm{nM}$ ribosomes by $5 \mu \mathrm{M}$ fully methylated $\mathrm{RF} 2{ }^{\mathrm{m}}$ without antibiotics, and with $500 \mu \mathrm{M}$ paramomycin or $500 \mu \mathrm{M}$ viomycin bound. ( $C-J$ ) Catalytic rate constants for peptide release in the absence or presence of antibiotics at different concentrations. $k_{\text {cat }}$ and $K_{1 / 2}$ of peptide release by $\operatorname{ArfA} \triangle 12 \mathrm{C} / \mathrm{RF} 2^{\mathrm{m}}$ on $\mathrm{A} 0$ nonstop mRNA $(C, D)$, by $\mathrm{RF}^{\mathrm{m}}$ on the stop codon UGA $(E, F)$, by ArfA $\Delta 12 \mathrm{C}$ / $\mathrm{RF} 2^{\mathrm{m}}$ on A3 mRNA $(G, H)$, and on A6 mRNA $(I, J)$ with different concentrations of antibiotics. 
UGA (Fig. 4E,F), supporting competitive binding of paromomycin and RF2. Thus, our data suggest a similar effect of the two antibiotics on canonical and nonstop termination pathways.

However, peptide release in the ribosome on A3 and A6 nonstop mRNAs showed increased sensitivity to paromomycin (Fig. 4G-J). The rates of peptide release decreased and $K_{1 / 2}$ increased (Fig. 4G-J), indicating different conformations of the nonstop complexes on A3 and A6 mRNAs compared to the one formed on A0 mRNA. The same effect of paromomycin on peptide release at a near-cognate codon was seen by Green and colleagues (Youngman et al. 2007).

Combining the binding results obtained in the previous section, our data strongly suggest that ArfA/RF2 decode a nonstop mRNA and hydrolyze the nascent peptide from the P-site tRNA by an induced-fit mechanism.

The end points of release reactions in the viomycin- and paromomycin-inhibited ribosomes were decreased (Fig. 4A, $\mathrm{B})$, suggesting changes of ribosomal conformation as a result of the binding of the antibiotics. Importantly, in contrast to the peptide release in the nonstop complexes on A6 and A9 mRNAs, elevating concentrations of $\mathrm{Mg}^{2+}$ helped to recover the compromised end points and led to an increased fraction of peptide release on the viomycin-bound ribosome with A0 mRNA bound (Supplemental Fig. S3B). This observation indicated that the antibiotic-bound ribosomes were trapped in a less active state for the peptide release. Addition of the magnesium ions helped the ribosome to recover from the less-active state, presumably through stabilizing RNA structures, and helped the system transit into an active state, thereby faciliating the progression of the hydrolytic reaction of peptide release.

\section{Effects of class II release factor RF3 on the ArfA/RF2- mediated peptide release in the ribosome}

Since our results thus far suggested a shared mechanism of peptide release on a nonstop mRNA by ArfA/RF2 and the release on a stop codon by RF2, we asked whether they also share the same immediate downstream event. In canonical translational termination, after the peptide release, in some species of bacteria including E. coli, a class II release factor and also a translational GTPase, RF3, binds to the ribosome in the GTP state and accelerates the disassociation of the RF1 or RF2. Finally, GTP hydrolysis on RF3 leads to the subsequent release of RF3 from the ribosome. The function of RF3 in translational termination was proposed by Ehrenberg and colleagues (Zavialov et al. 2001, 2002). Recent biochemical (Koutmou et al. 2014; Peske et al. 2014) and structural studies (Jin et al. 2011) showed that RF3 with GTP bound (RF3.GTP) tightly associates with the ribosome in its rotated state, promoting the disassociation of class I release factors RF1 or RF2.

However, counter-intuitively, RF3.GTP inhibited the peptide release by ArfA and RF2 when RF2 was present in excess (single-turnover peptide release), even though ArfA/RF2mediated termination is mechanistically similar to the RF2mediated termination at a stop codon, as shown in Figure 5. At a sub-stoichiometric concentration of RF2 (multiple turnover peptide release), the presence of RF3 did not promote peptide release by RF2 (Supplemental Fig. S4).

RF3.GTP binds to the ribosome in the hybrid state (Jin et al. 2011), but RF2 catalyzes peptide release in the classical state (Weixlbaumer et al. 2008; Jin et al. 2010). One possible explanation for the failure to stimulate peptide release is that unlike the termination at a stop codon by RF2, after the peptide release on a nonstop mRNA by ArfA/RF2, the presence of ArfA "locks" the ribosome and stabilizes the ribosome in a defined state, most likely a classical state, thereby preventing RF3.GTP from sampling a rotated state. In contrast, normal peptide release in the $\mathrm{P}$ site "unlocks" the ribosome, allowing the ribosomal subunits to rotate relative to each other, thus offering an opportunity for RF3-GTP to sample different states of the ribosome.

\section{DISCUSSION}

Bacterial class I release factor RF2, plays a unique function in the translational quality control. In resolving a nonstop translation, in addition to the tmRNA and SmpB, RF2 interacts with alternative ribosome rescuing factors to rescue the stalled ribosome.

In this study, we investigated the mechanism of peptide release on nonstop mRNAs in the ribosome by RF2 and alternative ribosome rescuing factor A in E. coli. We first reconstituted a well-defined in vitro system using purified components, and verified that ArfA binds to the $30 \mathrm{~S}$ and only recruits RF2 in the ribosome. RF1 was not recruited to a nonstop mRNA under all experimental conditions that we tested. We showed in the absence of ArfA, RF2 did not catalyze the peptide release on the nonstop RNA. ArfA substantially promotes the binding of the RF2 to the ribosome and the catalytic rate of the reaction of peptide release.

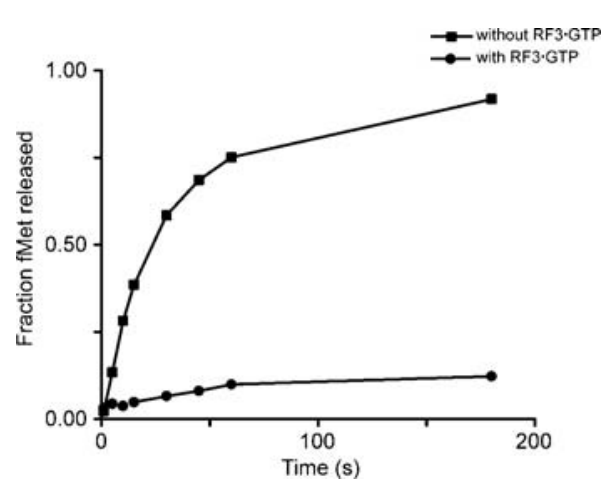

FIGURE 5. RF3.GTP inhibits the peptide release on a nonstop mRNA by ArfA $\triangle 12 \mathrm{C}$ and $\mathrm{RF}^{\mathrm{m}}{ }^{\mathrm{i}}$ in the ribosome. Time courses were obtained by incubating $25 \mathrm{nM}$ release complexes with $62.5 \mathrm{nM}$ ArfA $\Delta 12 \mathrm{C}$ and $1 \mu \mathrm{M}$ $\mathrm{RF} 2{ }^{\mathrm{m}}$ in the absence $(\mathbf{})$ or presence $(\bullet)$ of $15 \mu \mathrm{M}$ RF3.GTP. 


\section{An induced-fit mechanism for ArfA/RF2-catalyzed peptide release}

Using RF2 with methylated glutamine in the GGQ motif (termed $\mathrm{RF} 2^{\mathrm{m}}$ in this study), we studied the mechanism of ArfA/RF2-catalyzed peptide release in a nonstop translation. Several lines of evidence established that, ArfA and RF2 catalyzed the peptide release on a nonstop mRNA by an induced-fit mechanism.

First, we demonstrated that the more occupied mRNA channel downstream the ribosomal P site, the more drastic decrease of the rate constants of the peptide release (Fig. 3), although both ArfA and RF2 could bind to the ribosome with a similar affinity (Fig. 1). In general, peptide release by $\mathrm{RF}^{\mathrm{m}}$ on $\mathrm{A} 3, \mathrm{~A} 6$, and $\mathrm{A} 9$ is characterized by rapid decreases in the rate constant and moderate increases in the concentration of $\mathrm{RF} 2^{\mathrm{m}}$ required to achieve half of the $k_{\mathrm{cat}}\left(K_{1 / 2}\right)$. The $k_{\text {cat }}$ of the release reaction catalyzed by ArfA/RF $2^{\mathrm{m}}$ decreased by $50 \%$ on the A 3 mRNA, and it dropped to a much lower level that it was not measurable under our experimental conditions when A9 mRNA was present. On the A6 mRNA, the length of which is in between the A3 and A9, the overall kinetics of the release reaction resembled the one by RF2 on a near-cognate stop codon in canonical termination.

Second, the end points of the peptide release on A6 and A9 mRNAs decrease substantially compared with the ones on the A0 and A3 mRNAs, indicating different conformations of the enzyme-substrate complexes on the mRNA variants when both ArfA and RF2 bind to the ribosome.

Third, in the presence of ArfA, RF2 catalyzes the peptide release on a nonstop mRNA in the same way as RF2 does on a cognate stop codon. As shown in Table 1, kinetic parameters obtained from our experiments, $k_{\text {cat }}$ and $K_{1 / 2}$ of the fMet released by $\mathrm{ArfA} / \mathrm{RF}^{\mathrm{m}}{ }^{\mathrm{m}}$ on the A0 mRNA in the ribosome, were similar to those by $\mathrm{RF} 2^{\mathrm{m}}$ on a cognate stop codon UGA. Furthermore, the rates of peptide release in both systems, either catalyzed by ArfA/RF2 on a nonstop mRNA or promoted by RF 2 on a stop codon UGA, showed a similar degree of response to the $N^{5}$-methylation of the glutamine in GGQ motif of the RF2. This modification leads to $\sim 20$-fold increase in the $k_{\text {cat }}$ of the release reaction by RF2 on the A0 mRNA in the presence of ArfA, leaving the binding of RF2 to the nonstop complex largely unchanged. An $\sim 10$-fold change in the kinetics was observed on the peptide release by RF2 at the stop codon UGA. These results suggested that the two release pathways responded to the changes in the PTC in the same way. Assuming the rate-limiting step in the release pathway is not changed by the modification, our data indicated that $N^{5}$-methylation of the glutamine positions this residue in an optimal position for the catalysis in the PTC of the ribosome. Although methylation of the glutamine in the GGQ motif substantially increases the rate of peptide release on cognate stop codons, it has almost no effect on the rate constant catalyzed by the same protein on near-stop codons. The same effect of the modification on the rate of peptide release by ArfA/RF2 was observed on A3 and A6 mRNA, which suggested that an occupied mRNA channel downstream from the $\mathrm{P}$ site in the ribosome compromises an induction of a fully active state of the RF2.

Fourth, we demonstrated that the canonical and nonstop termination pathways responded to the perturbations of antibiotics viomycin and paromomycin in the same way. We showed that viomycin and paromomycin competed with RF2 to bind to the ribosome, with viomycin showing a more pronounced effect. As suggested by almost the same degrees of changes in $k_{\text {cat }}$ and $K_{1 / 2}$, the kinetic profiles of the release reactions catalyzed by ArfA/RF2 ${ }^{\mathrm{m}}$ on the A0 mRNA and by $\mathrm{RF}^{\mathrm{m}}$ on the UGA stop codon were very similar. Under 150 $\mu \mathrm{M}$ paromomycin, we demonstrated that the antibiotic did not affect the $k_{\text {cat }}$ of peptide release by ArfA $\Delta 12 \mathrm{C} / \mathrm{RF}^{\mathrm{m}}$ on A0 nonstop mRNA, whereas the $K_{1 / 2}$ were increased $\sim 10$ fold, suggesting a competitive binding model of paromomycin and RF2 on ribosome in the cognate decoding conditions.

However, different kinetic profiles were obtained in peptide releases on $\mathrm{A} 3$ and $\mathrm{A} 6$ mRNAs, characterized by a decrease in the $k_{\text {cat }}$ and simultaneous increase in the $K_{1 / 2}$ in the presence of paromomycin. The same kinetic profiles were seen in an earlier study on peptide release by RF1 on the near-cognate stop codon UCA/UAC codon (Youngman et al. 2007). These results suggest that A3/A6 mRNAs resemble the near-cognate decoding condition, and the stalled ribosome likely adopts a different conformation with longer mRNAs compared to the one when A0 mRNA is bound.

Taken together, our data support ArfA/RF2-catalyzed peptide release in the stalled ribosome by an induced-fit mechanism; $\mathrm{ArfA} / \mathrm{RF}^{\mathrm{m}}{ }^{\mathrm{m}}$ induce an active conformation which ultimately leads to optimal placement of the $\mathrm{GGQ}^{N 5-\mathrm{Me}}$ in the PTC to catalyze peptide release.

An induced-fit mechanism has been shown to be important for the tRNA selection in translational elongation (Pape et al. 1999) and stop codon recognition and peptide release in termination (Youngman et al. 2007). Here we showed that the same mechanism is used for the translational quality control. Termination of a protein synthesis when problematic translation occurs is an essential quality control mechanism that contributes to the accuracy and fidelity of the translation in all living cells. While different in the level of complexity and the details of molecular interactions, a release factor-like protein is involved in the quality control in all kingdoms of life. An important shared feature for all these processes is that the signal that intervention is required to originate in the decoding center of the ribosome and the actions that result in peptide release occur in the large ribosomal subunit. Therefore, it is not surprising that the molecular mechanism underlying this process is likely to be an induced-fit for every organism.

\section{Conformation of GGQ ${ }^{N 5-M e}$ in the PTC of the ribosome}

Based on the conclusion above, it is reasonable to gain insights into the molecular interactions of ArfA and RF2 on a 
nonstop mRNA in the ribosome from those of a cognate stop codon and RF2 in the canonical translational termination. It is demonstrated that highly specific protein-RNA interactions between the decoding loop of the RF2 and the stop codon determined the specificity of the stop codon recognition (Korostelev et al. 2008; Weixlbaumer et al. 2008). These interactions must be replaced by specific protein-protein interactions between ArfA and RF2.

In the PTC, the backbone of the GGQ motif of the RF2 is likely positioned the same way as the ones seen in the previous structures. Although eukaryotic, archeal, and bacterial class I release factors share little sequence or structural identity, the GGQ motif that is required for catalytic activity (Song et al. 2000; Mora et al. 2003) of the peptide release is universally conserved. In the crystal structure, the backbones of the two conserved glycines adopt a conformation that is not possible for any other amino acid (Korostelev et al. 2008, 2010; Laurberg et al. 2008; Weixlbaumer et al. 2008; Jin et al. 2010), explaining why their mutation results in loss of the catalytic activity of the release factor (Zavialov et al. 2002; Shaw and Green 2007). The conformation of the two glycines is obviously important to optimally place the glutamine in the GGQ motif in the PTC.

The glutamine is important for the peptide release. The main chain of this residue is critically involved in the catalysis. In all the canonical termination complexes, the main chain amide group is within hydrogen bond distance to the catalytic water, suggesting that it directly coordinates the water for the hydrolytic reaction in releasing the nascent peptide from the P-tRNA. Furthermore, it has been demonstrated that a substitution of a glutamine by a proline abolished the peptide release activity by RF2 without deforming the overall conformation of the GGQ motif in the PTC of the ribosome (Santos et al. 2013). In addition to the main chain amide group, the side chain of the glutamine has been implicated in providing important packing for specifically selecting a water molecule as the nucleophile for the release reaction, as proposed from a seminal biochemical investigation (Shaw and Green 2007). Consistent with the results, in the crystal structure of a release complex with a nonhydrolysable tRNA-peptide analog that represents the translational state right before the peptide release (Jin et al. 2010), conformation of the glutamine suggests that it creates a tightly packed pocket to accommodate a water molecule for the catalysis of the peptide release. Finally, molecular dynamic simulations showed the side chain of the glutamine made an entropic contribution to the hydrolytic reaction (Trobro and Aqvist 2009).

In line with the results obtained by earlier investigations, our kinetic data supported the view that $N^{5}$-methylation of the glutamine in the GGQ motif positions the catalytic glutamine in an optimal position for the catalysis in the PTC. The packing of the catalytic pocket by class I release factors in the PTC, conceivably, would be further facilitated by methylation of the glutamine. The observation that a Q240E mutant
(Q240 is the catalytic glutamine in the structure) has reasonable peptide release activity suggests a role for the carbonyl oxygen of Q240 in coordinating the catalytic water (Shaw and Green 2007). Therefore, methylation at the $N^{5}$ could help to position the amine away from the catalytic center and thus orient the carbonyl oxygen of the Q240 toward the water molecule for an optimal attack on the ester bond.

\section{Effects of RF3 on the peptide release by ArfA/RF2 ${ }^{\mathrm{m}}$ and in the ribosome}

The class II release factor RF3 in the GTP-binding state promotes the recycling of the class I release factors on the ribosome after the nascent peptide is released (Zavialov et al. 2001; Koutmou et al. 2014; Peske et al. 2014). Therefore, the presence of RF3-GTP increases the catalytic efficiency of the peptide release catalyzed by RF1 or RF2, but leaving the rate of the hydrolytic reaction unchanged in canonical termination. In contrast, RF3 does not promote recycling of the RF2 and ArfA in the nonstop complex. Instead, it inhibits the peptide release by ArfA and RF2 when RF2 is present in excess. These observations suggest that while mechanistically resembling a canonical termination on a cognate stop codon by RF2, ArfA/RF2-mediated termination on a nonstop mRNA likely proceeds toward a different downstream pathway that does not involve RF3 for immediate recycling.

\section{MATERIALS AND METHODS}

\section{Ribosome preparation, translation initiation, and release factors}

Ribosomes from E. coli MRE600 (a kind gift from Huang, R.H.) were purified as previously described (Shaw and Green 2007). E. coli IF1, IF2, and IF3 were overexpressed in BL21 (DE3) cells and purified with Ni-NTA column (Wolfrum et al. 2003). N-terminal His-tags in these proteins were removed by HRV-3C protease during purifications. E. coli Methionine-tRNA synthetase (MetRS) and methionyl-tRNA formyltransferase (FMT) were overexpressed in BL21 (DE3) cells and purified (Schmitt et al. 1996).

To obtain fully methylated $\mathrm{RF} 2^{\mathrm{m}}$, N-terminally His-tagged RF2 was coexpressed with its cognate methyltransferase (PrmC) in $E$. coli BL21 (DE3) strain under induction with $0.5 \%$ lactose at $25^{\circ} \mathrm{C}$ (Monteiro et al. 2000). N-terminally His-tagged RF3 from E. coli was expressed using the T5 vector pET-30. Both protein release factors were purified on a Ni-NTA affinity column, followed by ion-exchange chromatography and gel filtration (Jin et al. 2010, 2011). RF3.GTP was formed by incubating $15 \mu \mathrm{M}$ RF3 with $10 \mathrm{mM}$ GTP at $37^{\circ} \mathrm{C}$ for $10 \mathrm{~min}$.

The 12 C-terminal amino acids removed ArfA (designated as ArfA $\triangle 12 \mathrm{C}$ ) was cloned as described (Chadani et al. 2010, 2011). ArfA $\triangle 12 \mathrm{C}$ was overexpressed with the MBP fusion in BL21 (DE3) cells and purified using Ni-NTA in buffer A (25 mM Tris, pH 7.5, $200 \mathrm{mM} \mathrm{NaCl}, 0.1 \mathrm{mM}$ PMSF, and $0.1 \mathrm{mM}$ benzamidine). The MBP protein was removed by TEV protease after the purification step.

All E. coli ribosomes and proteins except IF2 were stored in buffer B (50 mM Tris, pH 7.4, $70 \mathrm{mM} \mathrm{NH}_{4} \mathrm{Cl}, 30 \mathrm{mM} \mathrm{KCl,} 10 \mathrm{mM} \mathrm{MgCl}_{2}$, 
and $5 \mathrm{mM} \beta$-mercaptoethanol) (Zaher and Green 2009; Petropoulos et al. 2014). E. coli IF2 was stored in buffer C (50 mM HEPES, pH 7.6, $1 \mathrm{M} \mathrm{NH}_{4} \mathrm{Cl}, 10 \mathrm{mM} \mathrm{MgCl}_{2}$, and $5 \mathrm{mM} \beta$-mercaptoethanol).

\section{Charged tRNA preparation}

tRNA $^{\mathrm{fMet}}$ was overexpressed and purified (Jin et al. 2010, 2011). Aminoacylation and formylation of $\mathrm{tRNA}^{\mathrm{fMet}}$ were performed with $\mathrm{L}-\left[{ }^{35} \mathrm{~S}\right]$-methionine (PerkinElmer) using MetRS and FMT as described (Walker and Fredrick 2008) with minor modifications. Briefly, $20 \mu \mathrm{M}$ tRNA ${ }^{\mathrm{fMet}}$ was incubated with $1 \mu \mathrm{M} \mathrm{L}-\left[{ }^{35} \mathrm{~S}\right]$-methionine, $0.6 \mathrm{mM}$ L-methionine, $12 \mu \mathrm{M}$ MetRS, $12 \mu \mathrm{M}$ FMT, $0.6 \mathrm{mM}$ 10 -formyltetrahydrofolate, $10 \mathrm{mM}$ ATP, and $0.02 \mathrm{U} / \mu \mathrm{L}$ pyrophosphatase in buffer D (100 mM HEPES-KOH, pH 7.6, $20 \mathrm{mM} \mathrm{KCl}$, $10 \mathrm{mM} \mathrm{MgCl}_{2}$, and $1 \mathrm{mM} \mathrm{DTT}$ ) at $37^{\circ} \mathrm{C}$ for $40 \mathrm{~min}$. The resulting fMet-tRNA $^{\text {fMet }}$ was then purified by Phenol:chloroform:isoamyl alcohol (25:24:1, v/v) and chloroform extraction followed by ethanol precipitation and dissolved in $2 \mathrm{mM} \mathrm{NaOAc}, \mathrm{pH}$ 5.2.

\section{mRNA}

mRNAs were purchased from Dharmacon (GE, Thermo Scientific) with the various sequences that are suitable for our studies. Sequences of mRNAs used in peptide release assays are listed as following (AUG in bold letters indicates the P-site codon):

\section{SD-PMet-UGA: GGCAAGGAGGAAAAAAUGUGAUACA}

SD-PMet-UGG: GGCAAGGAGGAAAAAAUGUGGUACA

SD-PMet-0 (A0): GGCAAGGAGGUAAAAAUG

SD-PMet-3 (A3): GGCAAGGAGGUAAAAAUGAAA

SD-PMet-6 (A6): GGCAAGGAGGUAAAAAUGAAAAAA

SD-PMet-9 (A9): GGCAAGGAGGUAAAAAUG AAAAAAAAA

SD-PMet-12 (A12): GGCAAGGAGGUAAAAAUGAAAAAAAAAAAA

\section{Release factor binding assay}

For the formation of a canonical termination complex, release complexes containing $70 \mathrm{~S}$ ribosome, $\mathrm{tRNA}^{\mathrm{fMet}}$ and mRNA with AUG and stop codons in the $\mathrm{P}$ and $\mathrm{A}$ sites, respectively, were formed. These complexes were incubated with fourfold excess of RF2 at $37^{\circ} \mathrm{C}$. For the formation of nonstop ribosomal complexes, nonstop mRNAs and twofold excess of ArfA $\triangle 12 \mathrm{C}$ were used instead.

For ArfA $\triangle 12 \mathrm{C}$-ribosome association assay, the nonstop ribosomal complex was passed through a $15 \%-30 \%$ sucrose gradient in buffer B at $68,300 \mathrm{~g}$ in a SW 32 Ti rotor for $15 \mathrm{~h}$. The $70 \mathrm{~S}$ peak was pooled and then dialyzed against buffer B with $2 \mathrm{mM} \mathrm{Mg}^{2+}$ instead of 10 $\mathrm{mM} \mathrm{Mg}^{2+}$. Ribosomal subunits were subsequently separated by a $15 \%-30 \%$ sucrose gradient in buffer B $\left(2 \mathrm{mM} \mathrm{Mg}^{2+}\right)$ at $68,300 \mathrm{~g}$ in a SW $32 \mathrm{Ti}$ rotor for $18 \mathrm{~h}$. The $50 \mathrm{~S}$ and $30 \mathrm{~S}$ peaks were collected and the association of ArfA $\Delta 12 \mathrm{C}$ was examined by Western blot using primary and secondary antibodies, monoclonal anti-polyhistidine (Sigma-Aldrich) and anti-Mouse IgG (whole molecule)Alkaline Phosphatase (Sigma-Aldrich), respectively.

Specificity assay recognitions of a stop codon by RF2 or a nonstop mRNA by ArfA $\triangle 12 \mathrm{C} / \mathrm{RF} 2$ were performed using size-exclusion chromatography on a Superdex 200 (10/300) column (Amersham/ GE Healthcare) and SDS-PAGE. Coomassie-stained SDS gels were used to show binding of RF2 to the ribosome, and Western blot was used to examine the binding of ArfA $\Delta 12 \mathrm{C}$ using Anti-Mouse
IgG $(\mathrm{H}+\mathrm{L})$ Antibody (Human Serum Adsorbed and Peroxidase Labeled, KPL) as the secondary antibody.

\section{Release complex formation}

Ribosomal complexes with P-site fMet-tRNA ${ }^{\mathrm{fMet}}$ were formed by incubating ribosome $(2 \mu \mathrm{M})$, mRNA $(6 \mu \mathrm{M})$, IF1, IF2, IF3 $(3 \mu \mathrm{M}$ each), GTP $(2 \mathrm{mM})$, and fMet-tRNA ${ }^{\text {fMet }}(3 \mu \mathrm{M})$ in buffer B at $37^{\circ} \mathrm{C}$ for $30 \mathrm{~min}$ (Zaher and Green 2009; Petropoulos et al. 2014). The reactions were then pelleted through $0.5 \mathrm{~mL}$ of $1 \mathrm{M}$ sucrose cushion in buffer B at 176,800g in a Type $45 \mathrm{Ti}$ rotor for $24 \mathrm{~h}$ (Zaher and Green 2009). The resulting complexes were resuspended in buffer $\mathrm{B}$, aliquoted, and stored at $-80^{\circ} \mathrm{C}$.

\section{Peptide release assay}

The kinetic experiment on peptide release was done essentially as described (Freistroffer et al. 2000; Zaher and Green 2009; Petropoulos et al. 2014) with modifications. First, ribosomal termination or nonstop complexes containing E. coli $70 \mathrm{~S}$ ribosomes, $\mathrm{f}-$ $\left[{ }^{35} \mathrm{~S}\right]-$ Met-tRNA ${ }^{\mathrm{fMet}}$ and mRNA with AUG codon in the P-site were formed as described in the previous section. The release complexes $(25 \mathrm{nM})$ reacted with an excess amount of RF2 $(5 \mu \mathrm{M})$ or ArfA $\Delta 12 \mathrm{C} / \mathrm{RF} 2(62.5 \mathrm{nM} / 5 \mu \mathrm{M})$ in buffer $\mathrm{B}$ at $37^{\circ} \mathrm{C}$. For the assays with antibiotics, the release complex $(25 \mathrm{nM})$ was first incubated with $500 \mu \mathrm{M}$ antibiotic at $37^{\circ} \mathrm{C}$ for $10 \mathrm{~min}$ (Youngman et al. 2007). The reactions were quenched by adding $5 \%$ ice cold trichloroacetic acid at different time points, and precipitants were spun down using $18,000 \mathrm{~g}$ for $10 \mathrm{~min}$ at $4^{\circ} \mathrm{C}$ to separate $\mathrm{f}-\left[{ }^{35} \mathrm{~S}\right]$-Met from $\mathrm{f}-\left[{ }^{35} \mathrm{~S}\right]-$ Met-tRNA ${ }^{\mathrm{fMet}}$. Subsequently, the supernatant was withdrawn and the released $\mathrm{f}-\left[{ }^{35} \mathrm{~S}\right]$-Met was counted in $5 \mathrm{~mL}$ of ScintiSafe Econo 1 Cocktail (Fisher Scientific). The maximum releasable fMet $\left(\mathrm{fMet}_{\mathrm{Max}}\right)$ was determined by incubating release complex $\left(25 \mathrm{nM}\right.$ ) with $100 \mu \mathrm{M}$ puromycin (Sigma-Aldrich) at $37^{\circ} \mathrm{C}$ for $30 \mathrm{sec}$ (Freistroffer et al. 2000). The fraction of $\mathrm{f}-\left[{ }^{35} \mathrm{~S}\right]$-Met was determined by the ratio between the released $\mathrm{f}-\left[{ }^{35} \mathrm{~S}\right]$-Met and $\mathrm{fMet}_{\text {Max }}$. The background level of released peptides in the absence of release factor was measured at the same time points and subtracted from each time point in the release reaction.

To determine the $k_{c a t}$ and $K_{1 / 2}, 25 \mathrm{nM}$ release complexes were reacted with different concentrations of release factors $(50 \mathrm{nM}-30$ $\mu \mathrm{M})$ during $1 \mathrm{sec}$ to $6 \mathrm{~min}$ depending on the kinetics of the reaction (Freistroffer et al. 2000). The fraction of released fMet $\left(F_{\mathrm{t}}\right)$ versus time was plotted and $k_{o b s}$ and reaction end point $\left(F_{\max }\right)$ were obtained by fitting the curve to single exponential equation $F_{\mathrm{t}}=$ $F_{\max } \cdot\left(1-\mathrm{e}^{-k o b s \cdot \mathrm{t}}\right)$. Alternatively, $k_{\mathrm{obs}}$ at each concentration was calculated using the equation $k_{\mathrm{obs}}=-\ln \left(1-F_{\mathrm{t}} / F_{\max }\right) / t$, which yielded to the same results. The $k_{\text {cat }}$ and $K_{1 / 2}$ were obtained by plotting $k_{\text {obs }}$ versus different concentrations of the release factor (RF) and fitting the curve using equation $k_{\mathrm{obs}}=k_{\mathrm{cat}} \cdot[\mathrm{RF}] /\left(K_{1 / 2}+[\mathrm{RF}]\right)$.

\section{SUPPLEMENTAL MATERIAL}

Supplemental material is available for this article.

\section{ACKNOWLEDGMENTS}

We thank Professor Peter B. Moore at Yale University for a critical review of the manuscript and Professor Hani Zaher at Washington 
University in St. Louis for helpful discussions on kinetic experiments. We also thank the Biotechnology Center at University of Illinois at Urbana-Champaign for the mass spectrometric analysis.

Received June 28, 2015; accepted October 1, 2015.

\section{REFERENCES}

Capecchi MR. 1967. Polypeptide chain termination in vitro: isolation of a release factor. Proc Natl Acad Sci 58: 1144-1151.

Caskey CT, Tompkins R, Scolnick E, Caryk T, Nirenberg M. 1968. Sequential translation of trinucleotide codons for the initiation and termination of protein synthesis. Science 162: 135-138.

Chadani Y, Ono K, Ozawa S, Takahashi Y, Takai K, Nanamiya H, Tozawa Y, Kutsukake K, Abo T. 2010. Ribosome rescue by Escherichia coli ArfA (YhdL) in the absence of trans-translation system. Mol Microbiol 78: 796-808.

Chadani Y, Matsumoto E, Aso H, Wada T, Kutsukake K, Sutou S, Abo T. 2011. Trans-translation-mediated tight regulation of the expression of the alternative ribosome-rescue factor ArfA in Escherichia coli. Genes Genet Syst 86: 151-163.

Chadani Y, Ito K, Kutsukake K, Abo T. 2012. ArfA recruits release factor 2 to rescue stalled ribosomes by peptidyl-tRNA hydrolysis in Escherichia coli. Mol Microbiol 86: 37-50.

Dincbas-Renqvist V, Engström A, Mora L, Heurgué-Hamard V, Buckingham R, Ehrenberg M. 2000. A post-translational modification in the GGQ motif of RF2 from Escherichia coli stimulates termination of translation. EMBO J 19: 6900-6907.

Fei J, Wang J, Sternberg SH, MacDougall DD, Elvekrog MM, Pulukkunat DK, Englander MT, Gonzalez RL Jr. 2010. A highly purified, fluorescently labeled in vitro translation system for singlemolecule studies of protein synthesis. Methods Enzymol 472: 221-259.

Freistroffer DV, Kwiatkowski M, Buckingham RH, Ehrenberg M. 2000. The accuracy of codon recognition by polypeptide release factors. Proc Natl Acad Sci 97: 2046-2051.

Frolova LY, Tsivkovskii RY, Sivolobova GF, Oparina NY, Serpinsky OI, Blinov VM, Tatkov SI, Kisselev LL. 1999. Mutations in the highly conserved GGQ motif of class 1 polypeptide release factors abolish ability of human eRF1 to trigger peptidyl-tRNA hydrolysis. RNA 5: 1014-1020.

Gagnon MG, Seetharaman SV, Bulkley D, Steitz TA. 2012. Structural basis for the rescue of stalled ribosomes: structure of YaeJ bound to the ribosome. Science 335: 1370-1372.

Garza-Sanchez F, Schaub RE, Janssen BD, Hayes CS. 2011. tmRNA regulates synthesis of the ArfA ribosome rescue factor. Mol Microbiol 80: 1204-1219.

Heurgué-Hamard V, Champ S, Mora L, Merkulova-Rainon T, Kisselev LL, Buckingham RH. 2005. The glutamine residue of the conserved GGQ motif in Saccharomyces cerevisiae release factor eRF1 is methylated by the product of the YDR140w gene. $J$ Biol Chem 280: 2439-2445.

Ito K, Uno M, Nakamura Y. 1998. Single amino acid substitution in prokaryote polypeptide release factor 2 permits it to terminate translation at all three stop codons. Proc Natl Acad Sci 95: 8165-8169.

Ito K, Uno M, Nakamura Y. 2000. A tripeptide 'anticodon' deciphers stop codons in messenger RNA. Nature 403: 680-684.

Ito K, Chadani Y, Nakamori K, Chiba S, Akiyama Y, Abo T. 2011. Nascentome analysis uncovers futile protein synthesis in Escherichia coli. PLoS One 6: e28413.

Ivanova N, Pavlov MY, Felden B, Ehrenberg M. 2004. Ribosome rescue by tmRNA requires truncated mRNAs. J Mol Biol 338: 33-41.

Jin H, Kelley AC, Loakes D, Ramakrishnan V. 2010. Structure of the 70S ribosome bound to release factor 2 and a substrate analog provides insights into catalysis of peptide release. Proc Natl Acad Sci 107: 8593-8598.

Jin H, Kelley AC, Ramakrishnan V. 2011. Crystal structure of the hybrid state of ribosome in complex with the guanosine triphosphatase release factor 3. Proc Natl Acad Sci 108: 15798-15803.
Keiler KC, Feaga HA. 2014. Resolving nonstop translation complexes is a matter of life or death. J Bacteriol 196: 2123-2130.

Klaholz BP, Pape T, Zavialov AV, Myasnikov AG, Orlova EV, Vestergaard B, Ehrenberg M, van Heel M. 2003. Structure of the Escherichia coli ribosomal termination complex with release factor 2. Nature 421: 90-94.

Korostelev A, Asahara H, Lancaster L, Laurberg M, Hirschi A, Zhu J, Trakhanov S, Scott WG, Noller HF. 2008. Crystal structure of a translation termination complex formed with release factor RF2. Proc Natl Acad Sci 105: 19684-19689.

Korostelev A, Zhu J, Asahara H, Noller HF. 2010. Recognition of the amber UAG stop codon by release factor RF1. EMBO J 29: 2577-2585.

Koutmou KS, McDonald ME, Brunelle JL, Green R. 2014. RF3:GTP promotes rapid dissociation of the class 1 termination factor. RNA 20: 609-620.

Kuhlenkoetter S, Wintermeyer W, Rodnina MV. 2011. Different substrate-dependent transition states in the active site of the ribosome. Nature 476: 351-354.

Kurita D, Chadani Y, Muto A, Abo T, Himeno H. 2014. ArfA recognizes the lack of mRNA in the mRNA channel after RF2 binding for ribosome rescue. Nucleic Acids Res 42: 13339-13352.

Laurberg M, Asahara H, Korostelev A, Zhu J, Trakhanov S, Noller HF. 2008. Structural basis for translation termination on the $70 \mathrm{~S}$ ribosome. Nature 454: $852-857$.

Modolell J, Vázquez. 1977. The inhibition of ribosomal translocation by viomycin. Eur J Biochem 81: 491-497.

Monteiro RA, Souza EM, Yates MG, Pedrosa FO, Chubatsu LS. 2000. Use of lactose to induce expression of soluble NifA protein domains of Herbaspirillum seropedicae in Escherichia coli. Can J Microbiol 46: 1087-1090.

Mora L, Heurgué-Hamard V, Champ S, Ehrenberg M, Kisselev LL, Buckingham RH. 2003. The essential role of the invariant GGQ motif in the function and stability in vivo of bacterial release factors RF1 and RF2. Mol Microbiol 47: 267-275.

Neubauer C, Gillet R, Kelley AC, Ramakrishnan V. 2012. Decoding in the absence of a codon by tmRNA and SmpB in the ribosome. Science 335: 1366-1369.

Pape T, Wintermeyer W, Rodnina M. 1999. Induced fit in initial selection and proofreading of aminoacyl-tRNA on the ribosome. EMBO J 18: $3800-3807$.

Peske F, Kuhlenkoetter S, Rodnina MV, Wintermeyer W. 2014. Timing of GTP binding and hydrolysis by translation termination factor RF3. Nucleic Acids Res 42: 1812-1820.

Petropoulos AD, McDonald ME, Green R, Zaher HS. 2014. Distinct roles for release factor 1 and release factor 2 in translational quality control. J Biol Chem 289: 17589-17596.

Petry S, Brodersen DE, Murphy FVT IV, Dunham CM, Selmer M, Tarry MJ, Kelley AC, Ramakrishnan V. 2005. Crystal structures of the ribosome in complex with release factors RF1 and RF2 bound to a cognate stop codon. Cell 123: 1255-1266.

Rawat UBS, Zavialov AV, Sengupta J, Valle M, Grassucci RA, Linde J, Vestergaard B, Ehrenberg M, Frank J. 2003. A cryo-electron microscopic study of ribosome-bound termination factor RF2. Nature 421: 87-90.

Santos N, Zhu J, Donohue JP, Korostelev AA, Noller HF. 2013. Crystal structure of the 70S ribosome bound with the Q253P mutant form of release factor RF2. Structure 21: 1258-1263.

Schaub RE, Poole SJ, Garza-Sánchez F, Benbow S, Hayes CS. 2012. Proteobacterial ArfA peptides are synthesized from non-stop messenger RNAs. J Biol Chem 287: 29765-29775.

Schmitt E, Mechulam Y, Ruff M, Mitschler A, Moras D, Blanquet S. 1996. Crystallization and preliminary x-ray analysis of Escherichia coli methionyl-tRNA(fMet) formyltransferase. Proteins 25: 139-141.

Scolnick E, Tompkins R, Caskey T, Nirenberg M. 1968. Release factors differing in specificity for terminator codons. Proc Natl Acad Sci 61: 768-774.

Shaw JJ, Green R. 2007. Two distinct components of release factor function uncovered by nucleophile partitioning analysis. Mol Cell 28: $458-467$. 
Shimizu Y. 2012. ArfA recruits RF2 into stalled ribosomes. J Mol Biol 423: 624-631.

Song H, Mugnier P, Das AK, Webb HM, Evans DR, Tuite MF, Hemmings BA, Barford D. 2000. The crystal structure of human eukaryotic release factor eRF1-mechanism of stop codon recognition and peptidyl-tRNA hydrolysis. Cell 100: 311-321.

Stanley RE, Blaha G, Grodzicki RL, Strickler MD, Steitz TA. 2010. The structures of the anti-tuberculosis antibiotics viomycin and capreomycin bound to the 70 S ribosome. Nat Struct Mol Biol 17: 289-293.

Trobro S, Aqvist J. 2007. A model for how ribosomal release factors induce peptidyl-tRNA cleavage in termination of protein synthesis. Mol Cell 27: 758-766.

Trobro S, Aqvist J. 2009. Mechanism of the translation termination reaction on the ribosome. Biochemistry 48: 11296-11303.

Walker SE, Fredrick K. 2008. Preparation and evaluation of acylated tRNAs. Methods 44: 81-86.

Weixlbaumer A, Jin H, Neubauer C, Voorhees RM, Petry S, Kelley AC, Ramakrishnan V. 2008. Insights into translational termination from the structure of RF2 bound to the ribosome. Science 322: 953-956.
Wilson KS, Ito K, Noller HF, Nakamura Y. 2000. Functional sites of interaction between release factor RF1 and the ribosome. Nat Struct Biol 7: 866-870.

Wolfrum A, Brock S, Mac T, Grillenbeck N. 2003. Expression in E. coli and purification of Thermus thermophilus translation initiation factors IF1 and IF3. Protein Expr Purif 29: 15-23.

Yamada T, Mizugichi Y, Nierhaus KH, Wittmann HG. 1978. Resistance to viomycin conferred by RNA of either ribosomal subunit. Nature 275: 460-461.

Youngman EM, He SL, Nikstad LJ, Green R. 2007. Stop codon recognition by release factors induces structural rearrangement of the ribosomal decoding center that is productive for peptide release. Mol Cell 28: 533-543.

Zaher HS, Green R. 2009. Quality control by the ribosome following peptide bond formation. Nature 457: 161-166.

Zavialov AV, Buckingham RH, Ehrenberg M. 2001. A posttermination ribosomal complex is the guanine nucleotide exchange factor for peptide release factor RF3. Cell 107: 115-124.

Zavialov AV, Mora L, Buckingham RH, Ehrenberg M. 2002. Release of peptide promoted by the GGQ motif of class 1 release factors regulates the GTPase activity of RF3. Mol Cell 10: 789-798. 

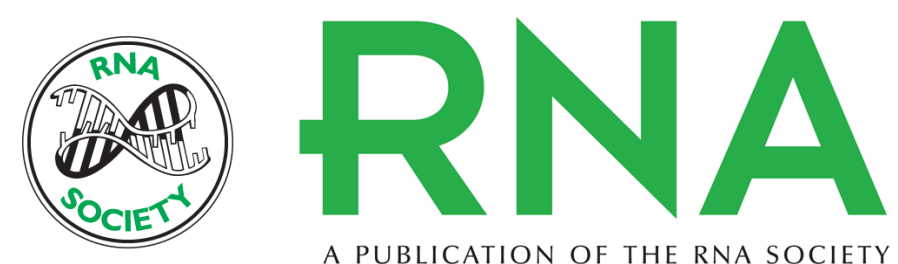

A PUBLICATION OF THE RNA SOCIETY

\section{Peptide release promoted by methylated RF2 and ArfA in nonstop translation is achieved by an induced-fit mechanism}

Fuxing Zeng and Hong Jin

RNA 2016 22: 49-60 originally published online November 9, 2015

Access the most recent version at doi:10.1261/rna.053082.115

\section{Supplemental http://rnajournal.cshlp.org/content/suppl/2015/11/03/rna.053082.115.DC1 Material}

References This article cites 54 articles, 20 of which can be accessed free at: http://rnajournal.cshlp.org/content/22/1/49.full.html\#ref-list-1

Creative This article is distributed exclusively by the RNA Society for the first 12 months after the Commons License full-issue publication date (see http://rnajournal.cshlp.org/site/misc/terms.xhtml). After 12 months, it is available under a Creative Commons License (Attribution-NonCommercial 4.0 International), as described at http://creativecommons.org/licenses/by-nc/4.0/.
Email Alerting Receive free email alerts when new articles cite this article - sign up in the box at the Service top right corner of the article or click here.

\section{|||||||| Providing Precise Solutions for your research.}

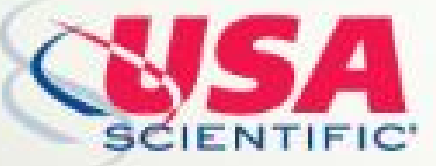

To subscribe to $R N A$ go to:

http://rnajournal.cshlp.org/subscriptions 